\title{
FORMULATION OF ANTIOXIDANT GEL FROM STANDARDIZED GREEN CINCAU (CYCLEA BARBATA L. MIERS) ETHANOLIC EXTRACT
}

\author{
ERLINDHA GANGGA ${ }^{1,}{ }^{*}$, YUNAHARA FARIDA ${ }^{1}$, KARTININGSIH ${ }^{1}$ \\ ${ }^{1}$ Faculty of Pharmacy, Pancasila University, Jakarta, 12640, Indonesia \\ Email: erlindha@gmail.com
}

Received: 23 May 2020, Revised and Accepted: 28 Sep 2020

\begin{abstract}
Objective: The aim of this study to develop an antioxidant gel from standardized green cincau (Cyclea barbata L. Miers) ethanolic extracts.

Methods: The standardized extract of green cincau (Cyclea barbata L. Miers) ethanolic extracts were formulated as active ingredients of antioxidant gel. The dried leaf of Cyclea barbata L Miers was extracted with ethanol 70\%. The extract was analyzed its phytochemical screening and antioxidant activity with DPPH methods. The extract was used as active ingredients of antioxidant gel. The gels were evaluated physically and chemically, such as organoleptic test, homogeneity, viscosity and rheology, spreadability, pH test, antioxidant activity, and analysis of microbial contamination test.

Results: The results showed that all formulas were greenish-yellow and have homogeneous, the viscosity of 14267-45533 cps, spreadability of gels 1783.8-6631.5 $\mathrm{mm}^{2}, \mathrm{pH}$ value of 4.57-5.74, and analysis of microbial contamination has colonies not more than $10^{3}$ colonies/g or colonies/ml. Statistical analysis used two ways ANOVA to investigate gels time and temperature effects toward gel preparations stability. There was no effect on the viscosity, spreadability, and $\mathrm{pH}$ tests, on the all formula with $\mathrm{P}>0.05$. The antioxidant activity of the formula showed that all formulas changed after 3 mo of storage at $40^{\circ} \mathrm{C}$. Formula II had stronger antioxidant activity than the others with an IC 50 value of $57.60 \mu \mathrm{g} / \mathrm{ml}$.
\end{abstract}

Conclusion: All formulas showed fairly strong antioxidant activity because it can inhibit the activity of free radicals that could inhibit the premature aging of the skin.

Keywords: Green cincau, Cyclea barbata L. Miers, Antiaging, Gelling agent, Antioxidant

(C) 2020 The Authors. Published by Innovare Academic Sciences Pvt Ltd. This is an open access article under the CC BY license (http://creativecommons.org/licenses/by/4.0/) DOI: http://dx.doi.org/10.22159/ijap.2020v12i6.38418. Journal homepage: https://innovareacademics.in/journals/index.php/ijap

\section{INTRODUCTION}

Indonesia is famous as an agricultural country producing a wide variety of plants that are useful among are other spices, herbs, vegetables, fruits, and others [1]. Over the past few years, some studies using plants carried out to get a variety of chemical compounds/secondary metabolites of various plants to be able to cope with a wide range of diseases such as diabetes, high blood pressure, respiratory infections, and everything related to the damage caused by a free radical [2]. Free radicals at the molecular level can cause damage to the cells. The antioxidant is a compound that could slow or prevent damage caused by free radicals. Antioxidants are powerful electron donor and react with free radicals that damage biomolecules, antioxidant radicals formed should be stable and not reactive.

The leaves of green grass jelly (Cyclea barbata Miers), also known as green cincau, have been commonly consumed in Indonesia. The Cyclea barbata Miers leaves or widely known as Green jelly leaves (GJL) when crushed with water, the water extract can form a gel spontaneously without the addition of ingredients at room temperature in a short period [3]. Green cincau (Cyclea barbata L. Miers) is a plant that people use as traditional medicine and can be processed into beverages [4]. Green cincau has antioxidant activity that can reduce free radicals [5]. Ethanolic extracts of Green cincau that have been obtained from standardized extract so is the quality of the extract has the antioxidant activity of the extract determined. Green cincau could be used as antiaging in the gel dosage form. Green cincau extract that has the most powerful antioxidant activity will be formulated in a gel dosage form using some formula.

Green cincau has lipoxygenase inhibitory activity [3], macrophage migration on burn wound [6], protective effects aspirin-induced gastric ulcer [7], protect from ROS in smoke, and antioxidant activity [5, 8, 9]. Green cincau leaves, besides containing flavonoids, also contain alkaloids, saponins, tannins, and steroids/triterpenoids [10]. These compounds work in synergy to increase antioxidant activity. Green cincau has the most active chemical content of alkaloids and flavonoids. Flavonoids act as a natural antioxidant to decrease the number of free radicals in the body, make it able to reduce/prevent the aging process, therefore [11]. Green cincau were traditionally developed as a pharmaceutical form due to its activity $[4,12,13]$. The gels formula used must be stable and meet physical quality requirements including inspection organoleptic on color, odor, and clarity, the examination of homogeneity, viscosity and flow properties, ability to spread, and $\mathrm{pH}$.

\section{MATERIALS AND METHODS}

\section{Materials}

Green cincau (Cyclea barbata L. Miers) leaves were obtained from the Medicinal Plant Garden, Research Institute for Spices and Medicinal Plants (Balittro), Bogor. The Cyclea barbata leaves has identified its taxonomic plant with the number 595/IPH.1.01/lf.07/IV/2018 at the Herbarium Bogoriense, Research Center for Biology, Indonesian Institute of Sciences (LIPI) Bogor, West Java, Indonesia. DPPH, methanol, carbomer 940, Sepigel 305, TEA, HPC-m, HPMC, Propylene glycol, methylparaben, propylparaben, sodium benzoate, edetate disodium, sodium metabisulfite, and ethanol were purchased from Qlab laboratory (Jakarta, Indonesia).

\section{Preparation of plants extracts}

The powdered leaves of Green cincau (Cyclea barbata L Miers) were dried and macerated with ethanol $70 \%$ at room temperature for 24 $\mathrm{h}$ the extract was repeated three times and the extract was subsequently concentrated using a rotary vacuum evaporator and stored in a freeze condition until used for further analysis [14].

\section{Phytochemical screening}

The phytochemical screening of Cyclea barbata L Miers has been performed according to Farnsworth's methods [15]. The determination of secondary metabolites has been done to examine the presence of alkaloids, flavonoids, saponins, tannins, quinones, steroids/terpenoids, coumarins, and volatile compounds.

\section{Antioxidant activity test}

The antioxidant activity of Green cincau (Cyclea barbata L Miers) extract and gels were tested using DPPH scavenging Methode. The 
protocol of the experiment extract was determined by the method of Brand-Williams et al. (1995) and Molyneux (2004) with slight modification [16, 17]. Briefly, the $0.1 \mathrm{mmol}$ DPPH solution was prepared in methanol. The standard curve was prepared using Vitamin C in a serial concentration of $0.2,0.4,0.8,1.6$, and $3.2 \mathrm{mg} / \mathrm{ml}$ the stock crude extracts were prepared by dissolving in methanol. These stocks were used for various concentrations were prepared in a concentration of 5, 10, 25, 50, and $100 \mathrm{ppm}$. Each sample concentration was mixed with $1.0 \mathrm{ml}$ of $1 \mathrm{mmol}$ methanolic DPPH solution. All the solutions were prepared with methanol up to $5.0 \mathrm{ml}$. The measurement was done by mixing $2 \mathrm{ml}$ of DPPH solution with 1 $\mathrm{ml}$ sample extract in the cuvettes and incubated for $30 \mathrm{~min}$ in the dark. The test sample was incubated for $30 \mathrm{~min}$. at room temperature and the absorbance was measured at $517 \mathrm{~nm}$ using a UV-visible spectrophotometer. Ascorbic acid was used as a standard and DPPH in methanol was used as a control. The difference in absorbance between the test and the control was calculated and expressed as \% scavenging of DPPH radical. Percent scavenging of DPPH free radical was measured using the following Eq.1:

$\%$ DPPH radical scavenging $=$ Absorbance of Control-Absorbance of Sample x 100 (1).

\begin{abstract}
Absorbance of control
Then \% inhibitions were plotted against the respective concentration used and from the graph IC 50 was calculated [18].

\section{Preparation of gel formula}

The formulation of the antioxidant gel was prepared in four formulas with different compositions of the gelling agent. The gelling agent was carbomer 940, sepigel 305, Hydroxy Propyl Cellulose (HPC-m), and Hydroxy Propyl Methyl Cellulose (HPMC). The composition of the gel was shown in table 1.
\end{abstract}

Table 1: Preparation of gel formula containing extract

\begin{tabular}{|c|c|c|c|c|c|}
\hline \multirow[t]{2}{*}{ No. } & \multirow[t]{2}{*}{ Ingredients } & \multicolumn{4}{|c|}{ Formula \% (w/v) } \\
\hline & & F1 & F2 & F3 & F4 \\
\hline 1 & Cyclea barbata xxtract & 0.0522 & 0.0522 & 0.0522 & 0.0522 \\
\hline 2 & Carbomer 940 & 0.5 & - & - & - \\
\hline 3 & Sepigel 305 & - & 3 & - & - \\
\hline 4 & Triethanolamine (TEA) & 0.5 & - & - & - \\
\hline 5 & HPC-m & - & - & 5 & - \\
\hline 6 & HPMC & - & - & - & 4 \\
\hline 7 & Propylene glycol & 15 & 15 & 15 & 15 \\
\hline 8 & Methylparaben & 0.03 & 0.03 & - & - \\
\hline 9 & Propylparaben & 0.01 & 0.01 & - & - \\
\hline 10 & Sodium benzoate & - & - & 0.1 & 0.1 \\
\hline 11 & Edetate disodium & 0.05 & 0.05 & 0.05 & 0.05 \\
\hline 12 & Sodium metabisulfite & 0.1 & 0.1 & 0.1 & 0.1 \\
\hline 13 & Ethanol & - & - & 40 & - \\
\hline 14 & Distilled water added until & 100 & 100 & 100 & 100 \\
\hline
\end{tabular}

The preparation of Formula I and II were dispersed carbomer 940 (gelling agent of formula 1) and sepigel 305 (gelling agent of formula 2 ) in distilled water at room temperature for $24 \mathrm{~h}$ with continuous stirring at $2000 \mathrm{rpm}$ in speed. Methylparaben and propylparaben were dissolved in propylene glycol. Sodium metabisulphite and edetate disodium were dissolved in distilled water and mixed with the Cyclea barbata extract. Finally, full mixed ingredients were mixed properly to the carbomer 940 gel with continuous stirring for 10-15 min. at $2000 \mathrm{rpm}$ speed until homogeny, than triethanolamine was added dropwise to the formulation to obtain the gel at the required consistency. The same method was followed for preparation with the gel base in table 1 . The accelerated stability was performed for $3 \mathrm{mo}$ at room temperature and $40{ }^{\circ} \mathrm{C} \pm 2{ }^{\circ} \mathrm{C}$ and $75 \% \pm 5 \%$ RH in the climatic chamber.

The preparation of gel Formula III and IV were made by dispersed carbomer 940 with distilled water at room temperature for $24 \mathrm{~h}$ and then homogenized with $2000 \mathrm{rpm}$ speed (as gelling agent). Triethanolamine (TEA) was dissolved in distilled water, then mix with carbomer 940 . Sodium benzoate, sodium metabisulfite, and edetate disodium were dissolved in distilled water and mixed with extract of Green cincau. Formula 3 used HPC-m and formula 4 used HPMC as a gel base. HPC-m and HPMC were dispersed with ethanol (as gelling agents).

\section{Evaluation of gel formulations}

The organoleptic observation was analyzed the color and odor of the gels were observed. The gel was analyzed its accelerated stability using ST Colgan methods [19]. The viscosity and rheology of different samples of gel formulations were determined at room temperature and $40{ }^{\circ} \mathrm{C}$ using a viscometer (Brookfield). The spreadability of different samples of gel formulations was determined with a spreadability tester at room temperature and 40 ${ }^{\circ} \mathrm{C}$. The $\mathrm{pH}$ measurement was determined using the electrode was submerged in gel until a stable $\mathrm{pH}$ value was obtained at room temperature and $40^{\circ} \mathrm{C}$.

\section{Microbial contamination examination}

Weigh one g of the sample accurately, put into $10 \mathrm{ml}$ volumetric flask, add phosphate buffer (pH 7.2) up to $10 \mathrm{ml}$. Total Plate Number was determined the total amount of bacteria, molds/yeasts. After the samples were prepared into the first tube to obtain (a 10-1 dilution), take $1 \mathrm{ml}$ of the liquid sample using a sterile pipette and diluted in $9 \mathrm{ml}$ of phosphate buffer solution to obtain a $10^{-2}$ dilution. Subsequent dilutions were made to $10^{-6}$. From each dilution, pipette $1 \mathrm{ml}$ into a sterile petri dish, then pour as much as 15 to $20 \mathrm{ml}$ of Nutrient Agar (NA) with a temperature of $45 \pm 1{ }^{\circ} \mathrm{C}$ for bacteria and $15-20 \mathrm{ml}$ of Potato Dextrose Agar (PDA) for molds/yeasts, and then shaken and rotated on a flat surface to obtain bacteria and molds/yeasts colonies spreadly growing. Once a petri dish solidifies, the petri dish was reversed and incubated in an incubator with a temperature of $35^{\circ}-37$ ${ }^{\circ} \mathrm{C}$ for $24-48 \mathrm{~h}(2 \mathrm{~d})$ for Nutrient Agar, and $25{ }^{\circ} \mathrm{C}$ for PDA for $1-7 \mathrm{~d}$. Colonies of bacteria, molds/yeasts, and fungi growing in a petri dish are then observed and counted. The result had to meet the requirements, according to Head of BPOM Regulation No. 17, 2014.

\section{Irritation study}

Irritation test was performed on men and women to all formulas. The permission of ethical clearance to conduct the irritation study was approved by the Health Research Ethics Committee, Faculty of Medicine, University of Indonesia, Jakarta, Indonesia (No. 772/UN.2. FI/ETIK/PPM.00.02/2019). The participant of this study was five healthy subjects (aged ranging from 25 to $40 \mathrm{y}$ old). They were briefed on the protocol study and approved an informed consent to conduct the procedure. Each formulation (FI, FII, FIII, and FIV) was applied once to each participant on a surface area of $5 \mathrm{~cm}^{2}$ on the forearm at a dose of $300 \mathrm{mg}$. The test specimen was thereafter washed off after $6 \mathrm{~h}$ by tap water and observed for any visible change such as erythema (redness) [20].

\section{Statistical analysis}

The statistical analysis was using two ways ANOVA to investigate time and temperature effects on the stability of the gel. 


\section{RESULTS AND DISCUSSION}

\section{Phytochemical screening}

The results of bioactive compounds detection in Cyclea barbata $\mathrm{L}$ Miers indicated that the ethanol extract contained potential bioactive compounds such as terpenoids, flavonoids, tannins, and phenolics compounds. Our findings provided evidence that the
Cyclea barbata L Miers crude extract contain medicinally important bioactive compounds. It justifies their potential use for the treatment of different diseases in traditional medicines [21].

\section{The antioxidant activity}

The antioxidant activity of Green cincau leaves extract was measured with ascorbic acid as control shown in table 1 .

Table 1: The antioxidant activity of green cincau leaves extract

\begin{tabular}{ll}
\hline Sample & $\mathbf{I C}_{\mathbf{5 0}}(\boldsymbol{\mu g} / \mathbf{m l})$ \\
\hline Green cincau leaves extract & $86.70+6.44$ \\
Ascorbic acid & 1.07 \\
\hline
\end{tabular}

Note: The data was given in mean $\pm \mathrm{SD} ; \mathrm{n}=3$

Table 1 showed that the extract exhibited potential antioxidant activities with an $\mathrm{IC}_{50}$ value of $86.70 \mu \mathrm{g} / \mathrm{ml}$. This finding indicated that crude extract Green cincau provides a possible antioxidant effect. Green cincau leaves are a herb that contains antioxidants such as flavonoid, natural compounds with potential as antioxidants [21]. Flavonoids also offer disease resistance; these are induced in response to UV-B radiation and provide organ protection by absorbing in the wavelength range of $280-350 \mathrm{~nm}$. They also function as reactive oxygen species (ROS) scavengers [5].

\section{Evaluation of gel formula}

Characteristic of gel formula of Green cincau extract of formula I-IV showed homogeneous, yellow-green viscous extract, odorless. Rheogram of the preparation of the gel of Formula I-IV were shown in table 2. The experiment was done in triplicate. Gels have a stable rheogram for three months, which are the plastic flow of the gel preparation did not change after 3 mo of storage.

The stability of the spreadability results of formula 1-4 was shown in table 3 . The spreadability of the gel decreased after 3 mo of storage due to the increase of viscosity, which increased every month. The best result came from formula number 4 where the gel remained stable on storage after 3 mo.

The $\mathrm{pH}$ stability evaluation results were shown in table $4 . \mathrm{pH}$ value at room temperature and $40{ }^{\circ} \mathrm{C}$ of the gels decreased within $3 \mathrm{mo}$. $\mathrm{pH}$ is affected by time. Formula 2 was more stable than the others. Three months of storage at room temperature made, the $\mathrm{pH}$ decreased from $5.17 \pm 0.02$ to $4.57 \pm 0$ and at $40{ }^{\circ} \mathrm{C}$ of 3 mo storage, the $\mathrm{pH}$ decreased from $4.76 \pm 0.01$ to $4.58 \pm 0.03$.

Table 2: Rheogram green cincau leaves extract gel preparation of formula I-IV

\begin{tabular}{llll}
\hline Formula & Time (months) & Room temperature (15-30 $\left.{ }^{\circ} \mathbf{C}\right) \boldsymbol{\eta}(\mathbf{c P s})$ & Temperature 40 $^{\circ} \mathbf{C} \boldsymbol{\eta}(\mathbf{c P s})$ \\
\hline I & 0 & $21633+989.94$ & nd \\
& 1 & $23000+94.75$ & $21267+1979.90$ \\
& 2 & $14533+1508.26$ & $18343+2531.44$ \\
II & 3 & $12567+989.95$ & $17533,5+4619.53$ \\
& 0 & $35033+5232.59$ & nd \\
& 1 & $36033.5+5421.39$ & $47567+2969.85$ \\
III & 2 & $37433.5+4478.11$ & $44066.5+2073.94$ \\
& 3 & $40900+519.02$ & nd \\
& 0 & $168535+829.44$ & $11467+1131.37$ \\
IV & 1 & $17200+565.69$ & $18133.5+3771$ \\
& 2 & $16667+565.69$ & $33333.5+9805.45$ \\
& 3 & $16800+1131.37$ & $35033+5232.59$ \\
& 0 & $35033+5232.59$ & $25033.5+1461.59$ \\
& 1 & $36033.5+5421.39$ & $26400+2640.34$ \\
\end{tabular}

Note: $n d=$ not detected; The data was given in mean $\pm S D ; n=2$

Table 3: Spreadability of green cincau leaves extract gel formula

\begin{tabular}{|c|c|c|c|c|c|}
\hline \multirow[t]{2}{*}{ Formula } & \multirow[t]{2}{*}{ Time (mo) } & \multicolumn{2}{|l|}{ Room } & \multicolumn{2}{|l|}{$40^{\circ} \mathrm{C}$} \\
\hline & & D (mm) & $\mathbf{F}\left(\mathrm{mm}^{2}\right)$ & $\mathrm{D}(\mathrm{mm})$ & $\mathbf{F}\left(\mathrm{mm}^{2}\right)$ \\
\hline \multirow[t]{4}{*}{ I } & 0 & $89.27+0.35$ & $6255.36+49.54$ & nd & nd \\
\hline & 1 & $87.59+2.25$ & $6024.79+309.5$ & $82.67+13.46$ & $5435.92+1746.73$ \\
\hline & 2 & $97.28+5.94$ & $7443.19+907.29$ & $80.23+5.44$ & $5063.95+684.33$ \\
\hline & 3 & $98.3+5.69$ & $7598.075+876.66$ & $85.98+8.58$ & $5832.59+1158.18$ \\
\hline \multirow[t]{4}{*}{ II } & 0 & $85.74+5.29$ & $5782.05+712.33$ & nd & nd \\
\hline & 1 & $75.42+3.18$ & $4468.835+376.74$ & $77.98+1.63$ & $4775.06+199.25$ \\
\hline & 2 & $73.95+1.98$ & $4294.49+229.73$ & $76.02+0.4$ & $4536.27+47.83$ \\
\hline & 3 & $68.35+0.71$ & $3667.78+75.79$ & $74.15+0.17$ & $4316.28+19.11$ \\
\hline \multirow[t]{4}{*}{ III } & 0 & $65.61+1.68$ & $3380.32+173.38$ & nd & nd \\
\hline & 1 & $65.61+1.78$ & $3380.47+183.06$ & $65.77+0.71$ & $3395.61+73.05$ \\
\hline & 2 & $65.68+1.92$ & $3387.57+197.78$ & $61.08+1.06$ & $2930.02+101.47$ \\
\hline & 3 & $65.67+2.21$ & $3387.385+227.85$ & $52.24+2.17$ & $2144.27+177.72$ \\
\hline \multirow[t]{4}{*}{ IV } & 0 & $50.65+0.45$ & $2042.95+34.76$ & nd & nd \\
\hline & 1 & $49.95+0.46$ & $1958.32+36.23$ & $51.09+1.78$ & $2050.58+142.85$ \\
\hline & 2 & $49.72+0.97$ & $1941.32+75.95$ & $48.67+0.76$ & $1859.92+57.8$ \\
\hline & 3 & $48.72+1.77$ & $1865.81+136.69$ & $48.15+0.68$ & $1820.33+51.65$ \\
\hline
\end{tabular}

Note: $n d=$ not detected; $\mathrm{D}=$ Diameter; $\mathrm{F}=$ Spreadability. The data was given in mean $\pm \mathrm{SD} ; \mathrm{n}=2$ 
Table 4: pH stability of green cincau leaves extract gels formula

\begin{tabular}{|c|c|c|c|c|c|}
\hline Temperature & Time (mo) & FI & FII & FIII & FIV \\
\hline Room temperature (15- & 0 & $5.92+0.02$ & $5.17+0.06$ & $6.34+0.04$ & $5.20+0.03$ \\
\hline \multirow[t]{3}{*}{$\left.30^{\circ} \mathrm{C}\right)$} & 1 & $6.01+0.01$ & $5.03+0.04$ & $6.29+0.05$ & $5.17+0.09$ \\
\hline & 2 & $5.85+0.05$ & $4.95+0.04$ & $6.17+0.08$ & $5.03+0.18$ \\
\hline & 3 & $5.71+0.08$ & $5.17+0.21$ & $6.05+0.01$ & $4.91+0.21$ \\
\hline \multirow[t]{4}{*}{$40^{\circ} \mathrm{C}$} & 0 & nd & nd & nd & nd \\
\hline & 1 & $5.98+0.04$ & $4.76+0.05$ & $6.14+0.17$ & $4.83+0.01$ \\
\hline & 2 & $5.84+0.01$ & $4.82+0.02$ & $5.95+0.18$ & $4.67+0.03$ \\
\hline & 3 & $5.73+0.01$ & $4.58+0.01$ & $5.87+0.15$ & $4.65+0.04$ \\
\hline
\end{tabular}

Note: $n d=$ not detected; The data was given in mean $\pm S D ; n=2$

The result of all evaluation shows the results of stability tests of FI, FII, FIII, and FIV, which include organoleptic test, homogeneity, $\mathrm{pH}$, and dispersion, showed that all gels did not show any change in visual organoleptic, homogeneity, and spreadability. There are no sign of phase separation. The all base of the green cincau gels are homogeneously mixed. Base on all evaluation, all gel formulas were included good semi solid categories. So the Cyclea barbata leaves can be potential made become skincare gel cosmetics that more profitable.

\section{The antioxidant activity of Cyclea barbata gel}

The antioxidant activity of Cyclea barbata gel formula was shown in table 5 .

Table 5: The antioxidant activity of green cincau gel formulations after $3 \mathrm{mo}$ of storage at $40{ }^{\circ} \mathrm{C}$

\begin{tabular}{|c|c|c|c|c|c|}
\hline \multirow[t]{2}{*}{ Temperature } & \multirow[t]{2}{*}{ Month } & \multicolumn{4}{|c|}{$\mathrm{IC}_{50}$ value $(\mu \mathrm{g} / \mathrm{ml})$} \\
\hline & & FI & FII & FIII & FIV \\
\hline Room Temperature & 0 & $61.37+0.56$ & $55.59+5.4$ & $69.35+1.89$ & $60.63+3.18$ \\
\hline $25-30{ }^{\circ} \mathrm{C}$ & 3 & $63.39+2.99$ & $57.36+6.24$ & $73.28+1.87$ & $65.12+3.06$ \\
\hline $40{ }^{\circ} \mathrm{C}$ & 0 & nd & nd & nd & nd \\
\hline & 3 & $67.71+0.04$ & $60.42+3.99$ & $82.19+14.21$ & $63.25+5.70$ \\
\hline
\end{tabular}

Note: The data was given in mean $\pm S D ; n=2$

The antioxidant activity of the formula showed that all formulas changed after $3 \mathrm{mo}$ of storage at $40{ }^{\circ} \mathrm{C}$. Formula 2 has stronger antioxidant activity than the others with an $\mathrm{IC}_{50}$ value of 57.60 $\mu \mathrm{g} / \mathrm{ml}$. The gel which was proven to have flavonoids showing antioxidant activity. Antioxidant activity analysis with DPPH free radical scavenging method showed that Green cincau leaves extract gel has a strong antioxidant activity with an $\mathrm{IC}_{50}$ value in the range of $57.60-92.24 \mu \mathrm{g} / \mathrm{ml}[22]$.

\section{Microbial contamination}

Microbial contamination of Green cincau gel formulations was shown in table 6 and table 7.

Table 6: Bacterial contamination of green cincau leaves extract gel formula

\begin{tabular}{|c|c|c|c|c|c|}
\hline \multirow[t]{2}{*}{ Formula } & \multirow[t]{2}{*}{ Temp. } & \multicolumn{3}{|c|}{ Concentration in $48 \mathrm{~h}$ incubation } & \multirow[t]{2}{*}{ TPN bacteria (cFu/g) } \\
\hline & & $10^{-1}$ & $10^{-2}$ & $10^{-3}$ & \\
\hline \multirow[t]{2}{*}{$\mathrm{I}$} & $25^{\circ} \mathrm{C}$ & $6.33+3.79$ & $2+1$ & $0.33+0.58$ & $<3 \times 10^{2}$ \\
\hline & $40{ }^{\circ} \mathrm{C}$ & $8.00+3.61$ & $5.33+4.04$ & $0.67+1.15$ & $<3 \times 10^{2}$ \\
\hline \multirow[t]{2}{*}{ II } & $25^{\circ} \mathrm{C}$ & $23.67+4.04$ & $8+2.65$ & 1 & $<3 \times 10^{2}$ \\
\hline & $40^{\circ} \mathrm{C}$ & $6.33+2.52$ & $4.33+2.52$ & $0.33+0.58$ & $<3 \times 10^{2}$ \\
\hline \multirow[t]{2}{*}{ III } & $25^{\circ} \mathrm{C}$ & $23.67+4.04$ & $12.67+3.51$ & $4.00+3.61$ & $<3 \times 10^{2}$ \\
\hline & $40^{\circ} \mathrm{C}$ & $33.67+2.52$ & $23.00+4.58$ & $8.00+2.00$ & $<3 \times 10^{2}$ \\
\hline \multirow[t]{2}{*}{ IV } & $25^{\circ} \mathrm{C}$ & $31.00+2.65$ & $26.67+1.53$ & $10.00+3.00$ & $3.2 \times 10^{2}$ \\
\hline & $40^{\circ} \mathrm{C}$ & $44.00+2.65$ & $25.33+4.04$ & $3.67+3.51$ & $4.4 \times 10^{2}$ \\
\hline
\end{tabular}

Note: TPN = Total Plate Number; The data was given in mean $\pm S D ; n=2$

Table 7: Fungal contamination of green cincau leaves extract gel formula

\begin{tabular}{|c|c|c|c|c|c|}
\hline \multirow[t]{2}{*}{ Formula } & \multirow[t]{2}{*}{ Temp. } & \multicolumn{3}{|c|}{ Concentration in $120 \mathrm{~h}$ incubation } & \multirow[t]{2}{*}{ TPN fungi (cFu/g) } \\
\hline & & $10^{-1}$ & $10^{-2}$ & $10^{-3}$ & \\
\hline \multirow[t]{2}{*}{$\mathrm{I}$} & $25^{\circ} \mathrm{C}$ & - & - & - & $<3 \times 10^{2}$ \\
\hline & $40^{\circ} \mathrm{C}$ & $1.33+0.58$ & $0.33+0.58$ & - & $<3 \times 10^{2}$ \\
\hline \multirow[t]{2}{*}{ II } & $25^{\circ} \mathrm{C}$ & $1+1$ & - & - & $<3 \times 10^{2}$ \\
\hline & $40^{\circ} \mathrm{C}$ & - & - & - & $<3 \times 10^{2}$ \\
\hline \multirow[t]{2}{*}{ III } & $25^{\circ} \mathrm{C}$ & $16.67+1.53$ & $5.67+1.15$ & - & $<3 \times 10^{2}$ \\
\hline & $40^{\circ} \mathrm{C}$ & $42.67+2.52$ & $17.00+2.00$ & $6.33+3.06$ & $<3 \times 10^{2}$ \\
\hline \multirow[t]{2}{*}{ IV } & $25^{\circ} \mathrm{C}$ & $35.33+2.52$ & $15+1.73$ & $2.33+2.31$ & $3.5 \times 10^{2}$ \\
\hline & $40^{\circ} \mathrm{C}$ & $75.33+2.52$ & $27.67+3.06$ & $5.00+1.00$ & $3.3 \times 10^{2}$ \\
\hline
\end{tabular}

Note: TPN = Total Plate Number; The data was given in mean \pm SD; $n=2$ 
The total number of bacteria and the total number of fungi of the gels were below the standard limit $10^{3}$ colony/g. The result showed that microbial contaminants in the gels formula were below the standard limit, following the requirements of Head of BPOM Regulation No. 17, 2014, and the Amended Regulation of Head of BPOM No. HK.03.1.23.07.11.6662. The level of microbial contamination in Cyclea barbata gel meets the standardization measures and quality control of herbal cosmetics [23].

\section{Irritation test}

Irritation test performed on men and women showed that all formulas did not irritate; thus it can be used for anti-aging gel. Therefore, all developed gel formulas might not irritate the skin and not causing irritant dermatitis. The evaluation of the skin irritancy of an herbal cosmetics formula is a necessity in the safety assessment of natural cosmetic ingredients [24].

\section{Statistical analysis}

Statistical analysis using two ways ANOVA to investigate time and temperature effects on the stability of the gel. There is no effect on viscosity, spreadability, and $\mathrm{pH}$ value on the first formula with $\mathrm{P}=$ $0.00>0.05$.

\section{CONCLUSION}

The results of phytochemical screening the ethanol $70 \%$ contained potential antioxidant compounds such as terpenoids, flavonoids, tannins, and phenolics. The ethanol extract of leaves of Green cincau can be formulated into dosage forms gel. The accelerated stability test shows the physical quality of is gelling agent of Formula 4 with HPMC $4 \%$ as gelling agent. Formula 4 has antioxidant activity with $\mathrm{IC}_{50}$ value of $59.22 \mathrm{ppm}$. Irritation test performed on men and women showed that all formulas did not cause irritation thus it can be used as anti-aging gel for skin.

\section{ACKNOWLEDGEMENT}

Special thanks are devoted for Directorate General of Higher Education of Indonesia which has given grants in this research.

\section{FUNDING}

The author acknowledge the funding from the Directorate General of Higher Education of Indonesia.

\section{AUTHORS CONTRIBUTIONS}

All the author have contributed equally.

\section{CONFLICT OF INTERESTS}

The authors have no conflict of interest to declare.

\section{REFERENCES}

1. Wathoni N, Haerani A, Yuniarsih N, Haryanti R. A review on herbal cosmetics in Indonesia. Int J Appl Pharm 2018;10:13-6.

2. Dua D, Srivastava NS. A study on antioxidant and anti-aging properties of few medicinal plants. Int J Pharm Pharm Sci 2016;8:344-7.

3. Handayani E, Nuraini P. Cyclea barbata leaf extract: lipoxygenase inhibitory activity and phytochemical screening. Int J Appl Pharm 2018;10(Special Issue 1):106-9.

4. Yuliarti O, Chong SY, Goh KKT. Physicochemical properties of pectin from green jelly leaf (Cyclea barbata Miers). Int J Biol Macromol 2017;103:1146-54.
5. Mahadi R, Rasyiid M, Dharma KS, Anggraini L, Nurdiyanti R, Nuringtyas TR. Immunomodulatory and antioxidant activity of green grass jelly leaf extract (Cyclea barbata miers.) in vitro. J Trop Biodivers Biotechnol 2018;3:73-9.

6. Sli DD, Riawan W, Rini IS, Wihastuti TA, Aprilianti IF, Ratnawati $\mathrm{R}$, et al. Effects of ethnaol cincau (Cyclea barbata Miers) leaves extract on macrophage migration on burn wound. Asian J Pharm Clin Res 2019;12:167-71.

7. Siregar IM, Miladiyah I. Protective effects of Cyclea barbata miers leaves against an aspirin-induced gastric ulcer in mice. Universa Med 2016;30:88-94.

8. Nurlela J. The effect of leaf green grass jelly extract (Cyclea barbata L. miers) to motility in mice balb/c male that exposed smoke. J Major 2015;4:57-63.

9. Thummajitsakul S, Sitthithaworn W, Silprasit K. High performance thin layer chromatography fingerprint and antioxidant activities of Cyclea barbata in Thailand. Agric Nat Resour 2019;53:479-86

10. Arkarapanthu A, Chavasit V, Sungpuag P, Phuphathanaphong L. Gel extracted from Khruea-ma-noi (Cyclea barbata Miers) leaves: chemical composition and gelation properties. J Sci Food Agric 2005;85:1741-9.

11. Pietta PG. Flavonoids as antioxidants. J Nat Prod 2000;63:1035-42.

12. Yuliarti $\mathrm{O}$, Hoon ALS, Chong SY. Influence of $\mathrm{pH}$, pectin and $\mathrm{Ca}$ concentration on gelation properties of low-methoxyl pectin extracted from Cyclea barbata miers. Food Struct 2017;11:16-23.

13. Yuliarti O, Othman RMB. Temperature dependence of acid and calcium-induced low-methoxyl pectin gel extracted from Cyclea barbata miers. Food Hydrocoll 2018;81:300-11.

14. Gangga E, Purwati R, Farida Y, Kartiningsih K. Determination of quality parameters and antioxidant activity of cincau hijau leaves (Cyclea barbata L. miers.). J Ilmu Kefarmasian Indones 2017;15:236-43.

15. Farnsworth NR. Biological and phytochemical screening of plants. J Pharm Sci 1966;55:225-76.

16. Brand Williams W, Cuvelier ME, Berset C. Use of a free radical method to evaluate antioxidant activity. LWT-Food Sci Technol 1995;28:25-30.

17. Molyneux P. The use of the stable free radical diphenylpicrylhydrazyl (DPPH) for estimating antioxidant activity. Songklanakarin J Sci Technol 2004;26:211-9.

18. Ghosal M, Mandal P. Phytochemical screening and antioxidant activities of two selected 'bihi'fruits used as vegetables in darjeeling himalaya. Int J Pharm Pharm Sci 2012;4:567-74.

19. Colgan ST, Mazzeo T, Orr R. Regulatory expectations and industry practice on stability testing. Accelerated Predictive Stability (APS). Elsevier Inc; 2018. p. 15-32.

20. Rahman SA, Abdelmalak NS, Badawi A, Elbayoumy T, Sabry N, Ramly A El. Formulation of tretinoin-loaded topical proniosomes for treatment of acne: in vitro characterization, skin irritation test and comparative clinical study. Drug Delivery 2015;22:731-9.

21. Takshak S. Bioactive compounds in medicinal plants: a condensed review. SEJ Pharm Nat Med 2018;1:1-35.

22. Blois MS. Antioxidant determinations by the use of a stable free radical. Nature 1958;181:1199-200.

23. DK SS, Jain V. Challenges in formulating herbal cosmetics. Int J Appl Pharm 2018;10:47-53.

24. Macfarlane M, Jones P, Goebel C, Dufour E, Rowland J, Araki D, et al. A tiered approach to the use of alternatives to animal testing for the safety assessment of cosmetics: skin irritation. Reg Tox Pharm 2009;54:188-96. 